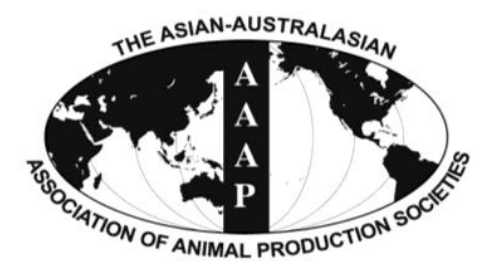

Asian Australas. J. Anim. Sci.

Vol. 26, No. 5 : 711-715 May 2013

http://dx.doi.org/10.5713/ajas.2012.12556

www.ajas.info

pISSN $1011-2367$ elSSN 1976-5517

\title{
Effect of Restricted Grazing Time on the Foraging Behavior and Movement of Tan Sheep Grazed on Desert Steppe
}

\author{
Yong Chen ${ }^{1,2}$, Hailing Luo ${ }^{1, *}$, Xueliang Liu ${ }^{1}$, Zhenzhen Wang ${ }^{1}$, Yuwei Zhang ${ }^{1}$, Kun Liu ${ }^{1}$, \\ Lijuan Jiao ${ }^{1}$, Yanfei Chang ${ }^{1}$ and Zhaoyun Zuo ${ }^{1}$ \\ ${ }^{1}$ State Key Laboratory of Animal Nutrition, College of Animal Science and Technology, \\ China Agricultural University, Beijing 100193, China
}

\begin{abstract}
To investigate the effect of restricted grazing time on behavior of Tan sheep on desert steppe, forty 4-months old male Tan sheep with an original body weight (BW) of $15.62 \pm 0.33 \mathrm{~kg}$ were randomly allocated to 4 grazing groups which corresponded to 4 different restricted grazing time treatments of $2 \mathrm{~h} / \mathrm{d}(\mathrm{G} 2), 4 \mathrm{~h} / \mathrm{d}(\mathrm{G} 4), 8 \mathrm{~h} / \mathrm{d}(\mathrm{G} 8)$ and $12 \mathrm{~h} / \mathrm{d}$ (G12) access to pasture. The restricted grazing times had a significant impact on intake time, resting time, ruminating time, bite rate and movement. As the grazing time decreased, the proportion of time spent on intake, bite rate and grazing velocity significantly $(p<0.05)$ increased, but resting and ruminating time clearly $(\mathrm{p}<0.05)$ decreased. The grazing months mainly depicted effect on intake time and grazing velocity. In conclusion, by varying their foraging behavior, Tan sheep could improve grazing efficiency to adapt well to the time-limited grazing circumstance. (Key Words: Restricted Grazing Time, Foraging Behavior, Tan Sheep, Movement, Desert Steppe)
\end{abstract}

\section{INTRODUCTION}

Grazing behavior is an important process directly associated with animal nutrition intake, productivity and impact on the grassland (DelCurto et al., 2005; Sanon et al., 2007; Laca, 2009). Understanding ruminants grazing behavior is vital for improving livestock management systems and reducing the environmental effects of intensive animal husbandry productions (Gibb, 2007; Clapham et al., 2011). Grazing management principally affects the grazing timing and length of grazing sessions which livestock require to meet their nutritional requirements for production (Holmes, 1989; Newman, 1994; Taweel et al., 2006). Lin et al. (2011) stated that sheep tended to maintain their grazing time at the expense of resting time to reduce the negative impact of shorter daylight duration on feed intake, and by behavior adaptation the sheep succeeded in maintaining their organic matter intake. Ayantunde et al. (2008) and Kennedy et al. (2009) demonstrated that restricting access

\footnotetext{
* Corresponding Author: Hailing Luo. Tel: +86-10-62734597, Fax: +86-10-62734597, E-mail: luohailing@ cau.edu.cn

2 College of Animal Science and Veterinary Medicine, Heilongjiang Bayi Agricultural University, Daqing, 163319, China.

Submitted Oct. 9, 2012; Accepted Dec. 20, 2012; Revised Jan. 18, 2013
}

time to pasture resulted in much greater grazing efficiency as the cattle with low access time spent a greater portion of their grazing time on foraging. Moreover, grazing livestock have the ability to change their intake rate as the consequence of behavioral decisions (Newman, 1994). Consequently, livestock with limited access to pasture moved more quickly, walked longer distances during grazing to maintain intake of sufficient forage mass (Garcia et al., 2005; Oudshoorn et al., 2008).

In northwest China with increasing human population density and decreasing land availability, animal husbandry is facing heavy grazing pressure and low vegetation cover, which led to further grassland degradation and ecological deterioration of the desert steppe (Chen et al., 2010). Thus, controlled grazing, rotational grazing or banning grazing was implemented to improve the ecological environment. As an important method for grazing management, biodiversity conservation and profitable animal production, restricted grazing time can satisfy the requirement of animals, herders, consumers and the environment. Therefore, understanding the behavioral implications of restricted grazing time is essential for grazing management and fragile ecosystems conservation. Tan sheep are raised in the desert and semi-desert regions of China, and are famous for their wool with long curled hair and high quality meat. 
To our knowledge, little information is available regarding the behavior of Tan sheep adjusting to time-limited grazing in the desert steppe. The objective of this study was to investigate the effect of restricted grazing time on the grazing behavior, bite rate, and movement of Tan sheep on the desert steppe.

\section{MATERIAL AND METHODS}

\section{Study site and swards}

The present study was carried out in the Sidunzi administrative village, Huamachi town, Yanchi County, Ningxia Hui Autonomous Region, China $\left(37^{\circ} 44\right.$ N, $107^{\circ} 19$ E; 1,400 $\mathrm{m}$ a.s.1.). The site is located on the southwest edge of the Maowusu desert and belongs to the interim zone of the Loess Plateau to the Ordos platform. The experimental area has the typical temperate continental monsoon climate. Annual mean temperature is $7.7^{\circ} \mathrm{C}$, average temperature in January is $-8.9^{\circ} \mathrm{C}$ and in July is $22.5^{\circ} \mathrm{C}$. Average annual precipitation is $289.5 \mathrm{~mm}$, which occurs mainly from July to September, and average annual evaporation capacity is $2,131.3 \mathrm{~mm}$. The steppe type is classified as arid sandy grassland.

\section{Animals and experimental design}

Forty male Tan sheep, purchased from local farms, were about 4-months old with an original body weight (BW) of $15.62 \pm 0.33 \mathrm{~kg}$, and were randomly allocated to one of four restricted grazing time treatments: Grazing $2 \mathrm{~h}$ per day $(\mathrm{G} 2$, grazing from 16:00 h to 18:00 h), $4 \mathrm{~h} / \mathrm{d}(\mathrm{G} 4$, from $6: 30 \mathrm{~h}$ to $10: 30 \mathrm{~h}), 8 \mathrm{~h} / \mathrm{d}(\mathrm{G} 8$, from $8: 30 \mathrm{~h}$ to $16: 30 \mathrm{~h})$, and $12 \mathrm{~h} / \mathrm{d}$ (G12, from $6: 30 \mathrm{~h}$ to $18: 30 \mathrm{~h}$ ). To supplement the quantity and quality insufficiency of pastures for grazing sheep, the amount of supplement was $300 \mathrm{~g}$ mixed feed at first 2 months and $500 \mathrm{~g}$ at last 2 months for G2, $150 \mathrm{~g}$ at first 2 months and $300 \mathrm{~g}$ at last 2 months for G4, $150 \mathrm{~g}$ at first 2 months and $300 \mathrm{~g}$ at last 2 months for G8 and nil for G12 treatments, respectively. The chemical composition and nutritive value of the mixed feed is given in Table 1. The sheep were fed with the supplement twice per day at $6: 00 \mathrm{~h}$ before grazing and 19:00 $\mathrm{h}$ after grazing within individual pens. After grazing, sheep were penned in paddocks and had free access to water.

The experiment was conducted during four consecutive months from June to September 2011. A $53.3 \mathrm{hm}^{2}$ wellproportioned vegetation plot was evenly separated to 4 paddocks (each $13.3 \mathrm{hm}^{2}$ ) by wire fences which were consistent with 4 experimental treatments. The plant mass was $167.61,192.83,203.23 \mathrm{~g} / \mathrm{m}^{2}$ in July, August and September, respectively (measured by sampling methods).

\section{Observation and recording of animal behavior}

Two Tan sheep in each experimental group were
Table 1. Ingredients and the chemical composition of experimental diets $(\mathrm{g} / \mathrm{kg} \mathrm{DM})$

\begin{tabular}{lr}
\hline Items & Concentrate \\
\hline Ingredients & \\
Corn & 595 \\
Wheat bran & 100 \\
Soy meal & 255 \\
Premix* & 50 \\
Chemical composition & \\
Crude protein & 191 \\
Digestible energy (MJ/kg DM) & 15 \\
Ash & 32 \\
NDF & 135 \\
ADF & 60 \\
Ca & 7 \\
P & 3 \\
\hline
\end{tabular}

* The premix per kilogram contains the following material: vitamin A (retinyl acetate), 120,000 IU; vitamin $\mathrm{D}_{3}, 18,000 \mathrm{IU}$; vitamin $\mathrm{E}$ (DL- $\alpha$ tocopheryl acetate), $500 \mathrm{IU}$; iron, $900 \mathrm{mg}$; copper, $150 \mathrm{mg}$; manganese , $1,160 \mathrm{mg}$; zinc, 1,900 mg; iodine, 11,000 mg; and selenium, $6 \mathrm{mg}$; cobalt, $6 \mathrm{mg}$; Ca $100 \mathrm{~g}$; P $30 \mathrm{~g}$; salt, $150 \mathrm{~g}$.

randomly chosen and labeled with different colored ribbon for behavioral survey. According to Hejcmanová et al. (2009) and Lee et al. (2010), on two days in the middle of July, August, and September (observing periods), the behavior of these two sheep was surveyed with the unaided eye and were recorded every 3 min-intervals during grazing time. Recorded activities time included i) grazing time (head down on the grass for browsing, biting and consuming herbaceous vegetation), ii) ruminating time (included standing and lying ruminating time), iii) resting time (immobile time on pasture included standing and lying resting time), iv) walking time (mobile time without grazing), v) other activity time (included the time of excretion and social interactions). The total time of each activity spent by the sheep was calculated as the product of the behavioral activity times and the 3 min-interval.

The walking distances of sheep were recorded every 30 $\mathrm{s}$ with one of the two focal sheep per plot by a Geographic Positioning System (GPS) receiver (Geosurvey330, UniStrong Inc., Beijing, China) during grazing observing days per months (Umstätter et al., 2008). GPS receivers (138 g/piece) were set in a hardy paper container and fitted to the back of sheep by harness. The grazing velocity was calculated as total grazing moving distance divided by the total grazing time.

To measure the bite rate (bites per min), a sheep per plot was randomly selected to record bite number per min using a hand-held counter for every $3 \mathrm{~min}$ and continuous for 30 $\min$. The results are expressed as average daily bite.

\section{Statistical analyses}

The sheep's activity value of different grazing 
treatments and different months were analyzed using General Line Model (GLM) procedure of SAS. The model was:

$$
y_{i j}=\mu+G_{i}+M_{j}+G \times M_{i j}+e_{i j}
$$

Where, $y, G, M$ and $e$ represented the target variable, the restricted grazing time $i$, the month $j$, the random experimental error, and $G \times M$ represented the interaction between restricted grazing time and month with companions. Multiple comparisons of the data were done by the Duncan test to determine the significant effects of different restricted grazing time and month. Statistical significance was identified at the $95 \%$ confidence level $(\mathrm{p}<0.05)$.

\section{RESULTS}

\section{Effect of restricted grazing time on grazing activities}

Restricted grazing time significantly reduced the proportion of resting, ruminating and walking activity time $(\mathrm{p}<0.01)$, which increased the proportion of intake time $(p<0.01)$. However, no difference of other activity time proportion was observed ( $>0.05$ ) (Table 2).

\section{Effect of restricted grazing time on bite rate, moving distance and velocity}

When Tan sheep were exposed to a short grazing time, a change in the bite rate was observed (Table 2). The bite rate of $\mathrm{G} 2$ group was significantly $(\mathrm{p}<0.05)$ higher than the other groups, and no significant difference of bite rate was observed amongst the other groups. By increasing the restricted grazing time, total moving distance of Tan sheep significantly $(\mathrm{p}<0.01)$ increased (Table 2$)$, and a notable difference among experimental groups was observed $(p<0.05)$. However, moving velocity significantly $(p<0.05)$ decreased with increasing restricted grazing time and the moving velocity of G2 group was higher than the other groups.

\section{Effect of grazing month on grazing activities}

Grazing month only had a clear effect on intake time, ruminating time and ruminating time proportion (Table 3 ). The intake time was lower in August than in July and September $(\mathrm{p}<0.05)$ and the proportion of intake time had a similar trend $(p>0.05)$. In different months, ruminating time and proportion were significantly $(\mathrm{p}<0.01)$ different, and the ruminating time was lower in September than in July and August. No significant influence was observed on the time spent on other activities.

\section{Effect of restricted grazing month on bite rate, moving distance and velocity}

The influence of grazing months on bite rate of Tan sheep was not significant ( $>00.05$ ), but the bite rate had an increasing trend with the progression of grazing months (Table 3). The moving distance was longer and the grazing velocity was swifter in September than in the other months $(\mathrm{p}<0.01)$, which had a clear increasing tendency with grazing months.

\section{DISCUSSION}

\section{Effect of restricted grazing time on behavior activity}

Animals could adapt to restricted access (time or quantity limited) at pasture by changing their foraging behavior to meet energy and nutrient requirements. The most likely reason was low forage intake enhancing hunger and motivating grazing (PéRez-RamíRez et al., 2008). The general behavior change of time-limited grazing was to

Table 2. Behavioral activity time and proportion of time spent at each activity of Tan sheep grazing on the desert steppe at four restricted grazing times (least squares means across the three grazing months)

\begin{tabular}{|c|c|c|c|c|c|c|}
\hline \multirow{2}{*}{ Parameter } & \multicolumn{4}{|c|}{ Group } & \multicolumn{2}{|c|}{ Probability values } \\
\hline & G2 & G4 & G8 & G12 & SEM & Grazing time \\
\hline Intake time (min) & $105.50^{\mathrm{d}}$ & $209.00^{c}$ & $375.50^{b}$ & $479.75^{\mathrm{a}}$ & 3.19 & $<0.01$ \\
\hline Resting time (min) & $5.00^{\mathrm{c}}$ & $9.75^{\mathrm{c}}$ & $28.75^{\mathrm{b}}$ & $80.50^{\mathrm{a}}$ & 1.79 & $<0.01$ \\
\hline Ruminating time (min) & $0.00^{\mathrm{d}}$ & $5.50^{\mathrm{c}}$ & $46.25^{b}$ & $101.00^{\mathrm{a}}$ & 1.48 & $<0.01$ \\
\hline Walking time (min) & $6.25^{\mathrm{d}}$ & $9.50^{\mathrm{c}}$ & $17.00^{\mathrm{b}}$ & $37.25^{\mathrm{a}}$ & 0.90 & $<0.01$ \\
\hline Other activity time (min) & $3.25^{\mathrm{d}}$ & $6.25^{\mathrm{c}}$ & $12.50^{\mathrm{b}}$ & $21.50^{\mathrm{a}}$ & 0.95 & $<0.01$ \\
\hline Bite rate (bite $\min ^{-1}$ ) & $53.56^{\mathrm{a}}$ & $46.85^{b}$ & $45.70^{\mathrm{b}}$ & $48.52^{b}$ & 1.49 & $<0.01$ \\
\hline Moving distance $(\mathrm{Km})$ & $2.77^{\mathrm{d}}$ & $3.99^{c}$ & $6.22^{\mathrm{b}}$ & $6.69^{\mathrm{a}}$ & 0.10 & $<0.01$ \\
\hline Grazing velocity $\left(\mathrm{m} \mathrm{min}^{-1}\right)$ & $26.57^{\mathrm{a}}$ & $18.46^{\mathrm{b}}$ & $14.36^{\mathrm{c}}$ & $10.51^{\mathrm{d}}$ & 0.39 & $<0.01$ \\
\hline Intake time $(\%)$ & $87.91^{\mathrm{a}}$ & $87.08^{\mathrm{a}}$ & $78.23^{b}$ & $66.63^{c}$ & 0.92 & $<0.01$ \\
\hline Resting time $(\%)$ & $4.17^{\mathrm{c}}$ & $4.06^{\mathrm{c}}$ & $5.99^{b}$ & $11.18^{\mathrm{a}}$ & 0.49 & $<0.01$ \\
\hline Ruminating time (\%) & $0.00^{\mathrm{d}}$ & $2.29^{c}$ & $9.64^{\mathrm{b}}$ & $14.03^{\mathrm{a}}$ & 0.26 & $<0.01$ \\
\hline Walking time $(\%)$ & $5.21^{\mathrm{a}}$ & $3.96^{\mathrm{b}}$ & $3.54^{\mathrm{b}}$ & $5.17^{\mathrm{a}}$ & 0.38 & $<0.01$ \\
\hline Other activity time $(\%)$ & $2.71^{\mathrm{a}}$ & $2.60^{\mathrm{a}}$ & $2.60^{\mathrm{a}}$ & $2.99^{\mathrm{a}}$ & 0.37 & 0.87 \\
\hline
\end{tabular}


Table 3. Behavioral activity time and rate of Tan sheep grazing on the desert steppe during different grazing months

\begin{tabular}{|c|c|c|c|c|c|}
\hline \multirow{2}{*}{ Parameter } & \multicolumn{3}{|c|}{ Month } & \multicolumn{2}{|c|}{ Probability values } \\
\hline & July & Aug. & Sept. & SEM & Month \\
\hline Intake time (min) & $292.69^{\mathrm{a}}$ & $286.69^{b}$ & $297.94^{\mathrm{a}}$ & 2.90 & $<0.01$ \\
\hline Resting time (min) & 30.38 & 32.81 & 29.81 & 1.55 & 0.36 \\
\hline Ruminating time (min) & $40.69^{\mathrm{a}}$ & $40.31^{\mathrm{a}}$ & $33.56^{\mathrm{b}}$ & 1.29 & $<0.01$ \\
\hline Walking time (min) & 16.50 & 18.38 & 17.62 & 0.78 & 0.24 \\
\hline Other activity time ( $\min$ ) & 9.75 & 11.82 & 11.06 & 0.82 & 0.21 \\
\hline Bite rate (bite $\min ^{-1}$ ) & 46.58 & 49.25 & 50.14 & 1.29 & 0.13 \\
\hline Moving distance $(\mathrm{Km})$ & 4.86 & 4.83 & 5.06 & 0.09 & 0.18 \\
\hline Grazing velocity $\left(\mathrm{m} \mathrm{min}^{-1}\right)$ & $14.80^{\mathrm{c}}$ & $17.95^{\mathrm{b}}$ & $19.66^{\mathrm{a}}$ & 0.34 & $<0.01$ \\
\hline Intake time $(\%)$ & 80.34 & 78.46 & 81.09 & 0.80 & 0.07 \\
\hline Resting time (\%) & 6.22 & 6.81 & 6.02 & 0.42 & 0.40 \\
\hline Ruminating time (\%) & $7.08^{\mathrm{a}}$ & $7.02^{\mathrm{a}}$ & $5.36^{\mathrm{b}}$ & 0.26 & $<0.01$ \\
\hline Walking time (\%) & 4.01 & 4.75 & 4.65 & 0.33 & 0.24 \\
\hline Other activity time $(\%)$ & 2.34 & 2.96 & 2.88 & 0.32 & 0.36 \\
\hline
\end{tabular}

intensify grazing activities (Newman, 1994). Similarly, the grazing time of Tan sheep in the present study was reduced from $479 \mathrm{~min}$ in $\mathrm{G} 12$ to $106 \mathrm{~min}$ in $\mathrm{G} 2$; however, the proportion of time spent grazing increased from $67 \%$ of G12 to $88 \%$ of G2. This adaptation of intake time was in response to the limited access to grassland (Iason et al., 1999; Jung et al., 2002; Gekara et al., 2005; Ginane and Petit, 2005). In addition, the animals could decrease their resting time, too. The rest time of Tan sheep in G2 and G4 group was less than 10 min during grazing. These results indicated that Tan sheep increased the proportion of intake time and decreased the proportion of rest time to improve foraging efficiency in compensation for the reduced access time to forage.

The intake time of Tan sheep was significantly lower in August than in July and September, respectively. The probable reason may be that the annual plant growth and forage production increased during the rainy season in JulyAugust. In addition, the high palatability and availability of vegetation in the growth phase and the increased energy requirements to build up reserves lead to an increased intake in September. The findings of Lin et al. (2011) was not consistent with our study, who reported that the sheep had less resting time so as to maintain more grazing time in September than in July and August. The possible reason for this discrepancy might be the day time was shorter for foraging in September than July and August in Lin's study while the Tan sheep in our study had the same amount of grazing time each month.

\section{Effect of restricted grazing time on bite rate}

It appears to be difficult to change the rhythm of bite rate (Taweel et al., 2006). However, in some extreme conditions, animals can change bite rates as an adaptation to methods aimed at improving the efficiency of using grassland and reducing the effect of intensive livestock on grassland (Newman, 1994; Gibb, 2007). Sheep significantly increased biting rate when exposed to declining grass availability (Galli et al., 2011). According to Ayantunde et al. (2008) and PéRez-RamíRez et al. (2008) dairy cows can also modify their intake rate in response to a constraint of access to pasture to maintain their intake and nutrient supply. In our study, Tan sheep had higher bite rate in the 2 $h$ grazing group than in the other groups, but there wasn't a significant difference between the other groups. This showed that the bite rate of sheep under normal conditions (without restricted time or access) is lower than their potential ability (Newman, 1994; Pérez-Prieto et al., 2011). There is more plant mass, especially annual plants, for foraging with rain falling in July and August and the greater herbage mass increases intake per bite, so the bite rate didn't show a significant difference with changing months.

\section{Effect of restricted grazing time on movement}

Shipley et al. (1996) and Etzenhouser et al. (1998) reported that animals modulated their foraging velocity to facilitate identification of resource availability. In low or limited resource conditions, an efficient and improved method of searching was observed in animals that allowed them to find the most available resource and suit to a high bite rate at pasture by adjusting their foraging speed. Tan sheep increased their walking speed with reducing restricted grazing time. The result of the present study is consistent with the other reports (Shipley et al., 1996; Etzenhouser et al., 1998; and Oudshoorn et al., 2008). The grazing velocity of Tan sheep significantly increased with progressing grazing months, and the trend was in line with the tendency of an increasing bite rate which was a more efficient method of grazing.

\section{CONCLUSIONS}

The present study indicated that Tan sheep have a strong behavioral ability to adapt to restricted grazing time by 
reducing the resting time, increasing intake time and walking speed, even changing bite rate to improve the efficiency of their grazing activity. Thus a regime of restricted grazing time of $4 \mathrm{~h}$ or even $2 \mathrm{~h}$ with an appropriate supplement may be able to maintain suitable grazing production on the desert steppe.

\section{ACKNOWLEDGEMENTS}

Authors are thankful to the projects of China Agricultural Ministry (200903060 and CARS-39) for financially supporting the present study and to $\mathrm{Mr}$. $\mathrm{Li}$ Kechang (Ningxia Hui Nationality Autonomous Region grassland stations) and Mr. Liu Yuhong (Ningxia Hui Nationality Autonomous Region Yanchi County grassland stations) for their kind help during the study.

\section{REFERENCES}

Chen, X. J., F. J. Hou, C. Matthew and X. Z. He. 2010. Stocking rate effects on metabolizable energy intake and grazing behaviour of Tan sheep in steppe grassland on the Loess Plateau of Northwest China. J. Agric. Sci. 148:709-721.

Clapham, W. M., J. M. Fedders, K. Beeman and J. P. S. Neel. 2011. Acoustic monitoring system to quantify ingestive behavior of free-grazing cattle. Comput. Electron. Agric. 76:96-104.

DelCurto, T., M. Porath, C. T. Parsons and J. A. Morrison. 2005. Management strategies for sustainable beef cattle grazing on forested rangelands in the Pacific Northwest. Rangel. Ecol. Manag. 58:119-127.

Etzenhouser, M. J., M. K. Owens, D. E. Spalinger and S. B. Murden. 1998. Foraging behavior of browsing ruminants in a heterogeneous landscape. Landsc. Ecol. 13:55-64.

Galli, J. R., C. A. Cangiano, D. H. Milone and E. A. Laca. 2011. Acoustic monitoring of short-term ingestive behavior and intake in grazing sheep. Livest. Sci. 140:32-41.

Garcia, F., P. Carrère, J. F. Soussana and R. Baumont. 2005. Characterisation by fractal analysis of foraging paths of ewes grazing heterogeneous swards. Appl. Anim. Behav. Sci. 93:1937.

Gekara, O. J., E. C. Prigge, W. B. Bryan, E. L. Nestor and G. Seidel. 2005. Influence of sward height, daily timing of concentrate supplementation, and restricted time for grazing on forage utilization by lactating beef cows. J. Anim. Sci. 83:1435-1444.

Gibb, M. 2007. Grassland management with emphasis on grazing behaviour. Frontis 18:141-157.

Ginane, C. and M. Petit. 2005. Constraining the time available to graze reinforces heifers' preference for sward of high quality despite low availability. Appl. Anim. Behav. Sci. 94:1-14.
Hejcmanová, P., M. Stejskalová, V. Pavlů and M. Hejcman. 2009. Behavioural patterns of heifers under intensive and extensive continuous grazing on species-rich pasture in the Czech Republic. Appl. Anim. Behav. Sci. 117:137-143.

Holmes, W. 1989. The utilization of pasture. Ruminant nutrition. Recommended allowances and feed tables (Ed. R. Jarrige), INRA., Paris-London, pp. 181-197.

Iason, G. R., A. R. Mantecon, D. A. Sim, J. Gonzalez, E. Foreman, F. F. Bermudez and D. A. Elston. 1999. Can grazing sheep compensate for a daily foraging time constraint? J. Anim. Ecol. 68:87-93

Jung, J., J. Yngvesson and P. Jensen. 2002. Effects of reduced time on pasture caused by prolonged walking on behaviour and production of Mpwapwa Zebu cattle. Grass Forage Sci. 57:105-112.

Laca, E. A. 2009. Precision livestock production: tools and concepts. Revista Brasileira de Zootecnia 38:123-132.

Lee, S., Y. Kim, Y. Oh and W. Kwak. 2010. Effects of feeding methods of total mixed ration on behavior patterns of growing Hanwoo steers. Asian Australas. J. Anim. Sci. 23:1469-1475.

Lin, L., U. Dickhoefer, K. Müller and A. Susenbeth. 2011. Grazing behavior of sheep at different stocking rates in the Inner Mongolian steppe, China. Appl. Anim. Behav. Sci. 129:36-42.

Newman, J. A., A. J. Parsons and P. D. Penning. 1994. A note on the behavioural strategies used by grazing dairy animals to alter their intake rates. Grass Forage Sci. 49:502-505.

Oudshoorn, F. W., T. Kristensen and E. S. Nadimi. 2008. Dairy cow defecation and urination frequency and spatial distribution in relation to time-limited grazing. Livest. Sci. 113:62-73.

Pérez-Prieto, L. A., J. L. Peyraud and R. Delagarde. 2011. Pasture intake, milk production and grazing behaviour of dairy cows grazing low-mass pastures at three daily allowances in winter. Livest. Sci. 137:151-160.

PéRez-RamíRez, E., R. Delagarde and L. Delaby. 2008. Herbage intake and behavioural adaptation of grazing dairy cows by restricting time at pasture under two feeding regimes. Animal 2:1384-1392.

Sanon, H. O., C. Kaboré-Zoungrana and I. Ledin. 2007. Behaviour of goats, sheep and cattle and their selection of browse species on natural pasture in a Sahelian area. Small Rumin. Res. 67:64-74.

Shipley, L. A., D. E. Spalinger, J. E. Gross, N. T. Hobbs and B. A. Wunder. 1996. The dynamics and scaling of foraging velocity and encounter rate in mammalian herbivores. Funct. Ecol. 10:234-244.

Taweel, H. Z., B. M. Tas, H. J. Smit, S. Tamminga and A. Elgersma. 2006. A note on eating behaviour of dairy cows at different stocking systems-diurnal rhythm and effects of ambient temperature. Appl. Anim. Behav. Sci. 98:315-322.

Umstätter, C., A. Waterhouse and J. P. Holland. 2008. An automated sensor-based method of simple behavioural classification of sheep in extensive systems. Comput. Electron. Agric. 64:19-26. 